\title{
MILKOVICH REVISITED: “SAVING” THE OPINION PRIVILEGE
}

\author{
EDWARD M. SUSSMAN
}

Language is a labyrinth of paths. You approach from one side and know your way about; you approach the same place from another side and no longer know your way about.

-Ludwig Wittgenstem ${ }^{1}$

\section{INTRODUCTION}

I wish to offer an explanation of Milkovich v. Lorain Journal Co. ${ }^{2}$ that "saves" the constitutional protection of the opinion privilege. I place "save" in quotation marks because I do not believe that the constitutional protection of the opinion privilege was lost, or even misplaced, by Milkovich - altliough the case has been misread in a manner that suggests otherwise. ${ }^{3}$ This Note reviews Milkovich, and rebuts a serious misunderstanding of the case that has found its way into several law reviews. ${ }^{4}$ The Note then discusses the constitutional diniensions of libel actions based on statements capable of inore than one reasonable interpretation.

Milkovich provided the Supresne Court with an opportunity to address squarely whether the broad category of speecli commonly labeled as "opinion" is afforded special protection by the Constitution. The case involved a libel suit brought against an Ohio newspaper. The suit alleged that a sports column appearing in the newspaper defained Michael

1. Ludwig Wittgenstein, Philosophical InVestigations \& 203 (1953).

2. 110 S. Ct. 2695 (1990).

3. See, eg., Anthony D'Amato, Harmful Speech and the Culture of Indeterminacy, 32 WM. \& MARY L. REv. 329, 343 n.56 (1991) (arguing that the Milkovich opinion is "incoherent" and suggesting that the Court may have wished to "encourage more libel lawsuits"); Nat Stern, Defamation, Epistemology, and the Erosion (But Not Destruction) of the Opinion Privilege, 57 TENN. L. REv. 595, 595 (1990) ("At a more significant and ominous level, Milkovich points to a tilt toward the less skeptical of the various and sometimes competing epistemological assumptions hitherto einployed by courts in deciding whether a statement is actionable as containing a factual accusation."); T.R. Hager, Note, Milkovich v. Lorain Journal Co.: Lost Breathing Space-Supreme Court Stiffes Freedom of Expression by Eliminating First Amendment Opinion Privilege, 65 TuL. L. REv. 944,952 (1991) (predicting as a result of Milkovich, "rising hibel hitigation" and "a severe chilling inipact," as well as stating that "the Supreme Court has unaniniously disposed of a useful tool for ensuring freedom of expression").

4. See supra note 3. 
Milkovich, a local high school wrestling coach. ${ }^{5}$ In its defense, the newspaper asserted that the sports column was protected by the First Amendment as a statement of opinion. 6 The Ohio Court of Appeals agreed, and affirmed summary judgment against Milkovich. ${ }^{7}$ The Supreme Court granted certiorari to consider the question of constitutional protection for statements of opinion, the Court's first direct examination of the issue. ${ }^{8}$ Previously, however, the Court had dealt extensively with related issues, ${ }^{9}$ and the doctrine developed by these cases forned the basis of what was widely recognized as a constitutional opinion privilege. ${ }^{10}$

In Milkovich, the Court declined to fashion "an additional separate constitutional privilege for "opinion." "11 But while reasserting existing doctrine, the Court emphasized the constitutional protection that statements of opinion already enjoyed, specifically holding that statements not asserting "actual facts" are not subject to hibel suit.12 In so doing, the Court was careful to state that merely labeling a statement "opinion," or inserting words such as "in my opinion" before a factual statement, is insufficient to trigger constitutional protection for the statement.13 "[C]ouching [factual] statements in [the] terins of opinion" does not create a blanket exemption from libel. ${ }^{14}$ Rather than creating "an artificial dichotomy between 'opinion' and fact," the Court stated that existing

5. See Milkovich, $110 \mathrm{~S}$. Ct. at 2699-700.

6. Id. at 2698.

7. See Milkovich v. News-Herald, 545 N.E. 2d 1320, 1324 (Ohio Ct. App. 1989).

8. See Milkovich, 110 S. Ct. at 2708 (Brennan, J., dissenting).

9. See Hustler Magazine, Inc. v. Falwell, 485 U.S. 46,50 (1988) (holding that the First Amendment protects an advertisement parody that could not reasonably be understood as describing "actual facts" about the public figure imvolved); Philadelphia Newspapers, Inc. v. Hepps, 475 U.S. 767, 777 (1986) (holding nnconstitutional the common-law presumption that defamatory speech is false); Old Dominion Branch No. 496, Nat'l Ass'n of Letter Carriers v. Austin, 418 U.S. 264, 284-86 (1974) (ruling that an accusation that an individual was a "traitor" for acting as a union "scab" was not a basis for a defamation action because the word "traitor" was used in a "loose, figurative sense" and was "merely rhetorical hyperbole, a lusty and imaginative expression of the contempt felt by union members"); Greenbelt Coop. Publishing Ass'n v. Bresler, 398 U.S. 6, 14 (1970) (rejecting the contention that a local newspaper's use of word "blackmail" describing a real estate developer's position implied that the developer actually committed the crime of blackmail).

10. See Milkovich, 110 S. Ct. at 2709 (Brennan, J., dissenting) (Thc majority ennloys "the sane indicia that lower courts have been relying on for the past decade or so to distinguish between statements of fact and statements of opinion: the type of language used, the meaning of the statement in context, whether the statement is verifiable, and the broader social circuinstances in which the statement was made.") (citations omitted).

11. Id. at 2707.

12. See id. at 2706 ("[W]e think that the 'breathing spacc' which 'freedouns of expression require in order to survive' is secured by existing constitutional doctine . ...") (citation omitted).

13. See id.

14. Id. 
doctrine requires an inquiry into the implied factual content of a statement. ${ }^{15}$

The Court's inquiry, limited as it is to implied and direct factual content, is not an "erosion," 16 but rather an affirmation of the Court's previous holdings regarding libel. Foremost, the Milkovich Court stated that for media defendants, Philadelphia Newspapers, Inc. v. Hepps ${ }^{17}$ requires that statements on matters of public concern "must be provable as false before there can be liability under state defamation law."18 Additionally, the Milkovich Court lield that Greenbelt Cooperative Publishing Ass'n v. Bresler, ${ }^{19}$ Old Dominion Branch No. 496, National Ass'n of Letter Carriers v. Austin, ${ }^{20}$ and Hustler Magazine, Inc. v. Falwell 21 "provide protection for statements that cannot 'reasonably [be] interpreted as stating actual facts' about an individual."22

In applying this existing constitutional doctrine to the newspaper column under examination in Milkovich, the Court applied three criteria. First, whether the stateinent contained "the sort of loose, figurative or hyperbohic language which would negate the impression that the writer was seriously maintaining" the alleged factual assertion. ${ }^{23}$ Second, whether "the general tenor of the article negate[s] this impression."24 Finally, whether the assertion is "sufficiently factual to be susceptible of being proved true or false." 25 In other words, the question is whether tenor, context, and provability indicate that a stateinent asserts a "fact."

As others have already noted, although perhaps without sufficient explanation, ${ }^{26}$ this articulation of the constitutional opinion privilege differs only in semantics froin the pre-Milkovich opinion privilege, as cominonly applied. ${ }^{27}$ In substance, the privilege remains identical. Concerns

\section{See id.}

16. See Stern, supra note 3.

17. 475 U.S. 767 (1986).

18. Milkovich, 110 S. Ct. at 2706.

19. 398 U.S. 6 (1970).

20. 418 U.S. 264 (1974).

21. 485 U.S. 46 (1988).

22. Milkovich, 110 S. Ct. at 2706 (quoting Falwell, 485 U.S. at 50). For an excellent overview of libel law, see Lucas A. POWE, The Fourth Estate AND tHe Constitution: Freedom of THE PRESS IN AMERICA (1991).

23. Milkovich, 110 S. Ct. at 2707.

24. Id.

25. Id.

26. See, e.g., The Supreme Court, 1989 Term-Leading Cases, 104 HaRv. L. REv. 219, 223 (1990) ("The standard articulated by the Milkovich Court for determining when a statement is an actionable assertion of fact is essentially the same as that the lower courts have used for years to distinguish between fact and opinion.").

27. See infra text accompanying uotes 93-104. 
that the opinion privilege has been "disposed" of, 28 or that the decision signals an "ominous" tilting toward the finding of actionable statements, ${ }^{29}$ are unwarranted from the Milkovich opinion itself. ${ }^{30}$ For although the newspaper sports column at issue in Milkovich is full of the sort of opinion statements previously understood to be exempt from libel actions, ${ }^{31}$ in the end, all the Milkovich Court does is apply its "new" articulation of the opinion privilege to the column's factual content, leaving undisturbed all of the column's "pure" opinion content. ${ }^{32}$ In short, the Court maintained the status quo. It held that assertions of fact, whether impled or directly stated, if false and defanatory, may be the subject of a tibel suit. ${ }^{33}$

Why, then, the confusion and concern found in law review articles ${ }^{34}$ and the profound misapplication of Milkovich found in at least one recent state supreme court case? ${ }^{35}$ I submit the following: Read without close attention to Chief Justice Rehnquist's exphicit instruction as to how the passage in question is to be tested for the truth of its factual content, the apphication of the Milkovich test inight seem to indicate that the column's "pure" opinion statements are potentially defamatory. ${ }^{36}$ Yet such

28. See Hager, supra note 3 , at 952 .

29. See Stern, supra note 3 , at 595 .

30. Of course, too much concern may itself be cause for concern if lower courts are misled into beheving that the constitutional opinion privilege has been weakened. See, e.g., Spence v. Flynt, 816 P.2d 771 (Wyo. 1991), discussed infra text accompanying notes 159-73. I do not mean to imply that lower courts, in general, have been misapplying Milkovich. Examples of published opinions that correctly apply Milkovich include Foretich v. Glamour, 753 F. Supp. 955,966 (D.D.C. 1990) ("The ultimate fact must then be such that plaintiff can prove its falsity; thus some generalized opinions or 'rhetorical hyperbole' often found in the media are privileged even though they may be said to place a person in an unfair or unfavorable light.") and Don King Prods., Inc. v. Douglas, 742 F. Supp. 778, 781-85 (S.D.N.Y. 1990) (holding that remarks by a boxing promoter, to the effect that Mike Tyson should have been declared the winner of a match with the boxer Buster Douglas, were protected opinions under Milkovich).

31. See infra tcxt accompanying notes 74-86.

32. See Milkovich, 110 S. Ct. at 2706-07. The term "pure" opinion is not that of the Supreme Court, but is borrowed from the RESTATEMENT (SECOND) OF TORTS $\S 566$ (1977). The Milkovich Court probably avoids the term "pure" opinion because it does not fully convey that an implied statenent of fact underlying an opinion statement may still be considered libelous. Used in this Note, the term "pure" opinion is not intended to encompass those statenents of opinion that, in context, imply potentially libelous facts. Rather, the term "pure" opinion is used because it provides a convenient shorthand form to describe the category of statenents identified by Milkovich as not sufficiently factual to be reasonably labeled "true" or "false."

33. See Milkovich, $110 \mathrm{~S}$. Ct. at 2706-07.

34. See supra note 3. 159-73.

35. See Spence v. Flynt, 816 P.2d 771 (Wyo. 1991), discussed infra text accompanying notes

36. See infra text accompanying notes $117-20$. 
an inclusion of "pure" opinion would make the Milkovich test "incoherent" 37 because it is an apphication that is unintended by the Court and for which the Milkovich test is ill suited. If Milkovich were read to invite scrutiny into "pure" opinions (such as many of those in the sports column), then the change in tibel law would be radical and unsettling, as some have suggested. 38

But if the Court had intended to eliminate constitutional protection for opinion, it would not have devoted energy to distinguishing stateinents that do garner constitutional protection froin those that do not. ${ }^{39}$ Indeed, deciding when a statement is "pure" opinion (that is, a statement identified by Milkovich as having the characteristics that require protection by the Constitution; in other words-not reasonably subject to being found "true" or "false" by a jury), and when it is soinething else, is the central problein of Milkovich.

The sports colunin at question in Milkovich provides a good forum to explore this problem because it contains statements of both "pure" and "couched" opinion.40 Most of the statements of "pure" opinion in the Milkovich colunin relate to the actions of high school wrestling coach Michael Milkovich at a team nreet. For example, the colunin states that "Milkovich's ranting from the side of the inat and egging the crowd on against the meet official and the opposing team backfired ... and resulted in ... a braw1 . ..."41 Because the "fact" that the coach made gestures

37. See D'Amato, supra note 3, at 343 n.56.

38. See, e.g., Hager, supra note 3, at 952.

39. See Milkovich, $110 \mathrm{~S}$. Ct. at 2705-06.

40. For instance, the statement "that painting is ugly" is "pure" opinion. I do not mean to suggest that in linguistic terms a statement can be rigorously characterized as "opinion" or "fact." Even the statement "that painting is ugly" operates on more than one level. It asserts, in an "opinion," the speaker's evaluation of the painting's aesthetic worth. But it also asserts, as "fact," that the painting exists. One might inuagine a scenario where the mere assertion of the painting's existence could be defannatory and, thus, even this statement of "pure" opinion could be the subject of a libel action. In no circumstance, however, could a jury reasonably decide the "truth" of the speaker's characterization of the painting as "ugly." This is because some words and statements are subject to interpretative variance too wide for a jury to decide reasonably that one interpretation is "true" and another "false." See discussion infra text accompanying notes 130-34.

By contrast, the statement, "in my opinion, Jack robbed the bank at the corner of Main and Spring Streets" conveys a factual assertion, albeit an assertion "couched" in the terms of opinion. This "factual" assertion is reasonably subject to being found "true" or "false" by a jury. But, just as I do not wish to suggest that statements of "pure" opinion are devoid of "fact" content, I also do not wish to suggest that statements of "fact" are devoid of a range of interpretation similar to statements of "opinion." For example, depending on context, the word "robbed" inight mean "held up the bank teller at gun point," or the word "robbed" inight mean "cleverly took advantage of the bank's unusually high interest rates by opeimig an account." However, by "facts," I mean those statenients that in context have a suitably narrow range of reasonable interpretation such that juries can decide if the meaning conveyed by the statement corresponds as "true" or "false" to a state of events.

41. Ted Diadiun, Maple Beat the Law with the "Big Lie," The News-Herald (Willoughby, Ohio), Jan. 8, 1975, at 39, quoted in Milkovich, 110 S. Ct. at 2698-99 n.2. 
and said words at the meet, and that there was a fight, was not disputed by Milkovich, ${ }^{42}$ the statement's remaining meaning concerns the characterization of the words and gestures, and the question of whether the words and gestures aroused violence in the crowd. These later "opinions" are subject to such wide interpretation that a jury could not reasonably decide if they are "true" or "false." 43

By contrast, the column also contains "couched" opinion. For example, it states that before attending a court hearing, Milkovich and the school superintendent "apparently had their version of the incident polished and reconstructed" from the time of an earher hearing.44 The word "apparently" functions in this sentence similarly to the words "in my opimion." Without the word "apparently," the sentence would be a direct statement of "fact" indicatimg that the men, in some manner, had changed their story. This indication of change is reasonably subject to being found "true" or "false" by a jury. ${ }^{45}$ When reviewed as part of the entire column, the statement's tenor, context, and provability indicate that the accusation of a change in testimony can be regarded as "fact." 46

The precise method that the Milkovich Court specifies for ascertainmg whether defamation occurred indicates that a distimction between "pure" opimion and "couched" opinion remains im the law, and that only the latter may properly be subject to a libel suit. More specifically, the Court states that the alleged defamation is to be established "on a core of objective evidence by comparing" the testimony at the two hearings stemming from the fight. ${ }^{47}$ Such a comparison would reveal whether there was a change im Milkovich's testimony from the first to the second hearing. This alleged change in testimony is the subject of the "couched" opimion sentence, quoted above. ${ }^{48}$ Comparing the two testimony records would not reveal whether Milkovich encouraged the altercationwhether the testimony between the two hearings is the same or different says nothing about the cause of the altercation. The cause of the altercation is the subject of the "pure" opinion sentence, quoted above. 49

42. See Milkovich, 110 S. Ct. at 2713 n.9 (Brennan, J., dissenting).

43. See infra text accompanying notes 130-34.

44. Diadiun, supra note 41 , at 39 (emphasis added).

45. The words "polish" and "reconstruct" are also capable of interpretation. But regardless of whether reasonable jurors would agree on the exact degree of change implied, at a minimum the words inply that some alteration occurred. Testing the proposition that testimony was altered is a relatively objective task. Trial transcripts could be compared for consistency without jurors having to agree on an exact definition of "pohish" or "reconstruct."

46. See infra text accompanying notes 123-25.

47. Milkovich, 110 S. Ct. at 2707.

48. See supra text accompanying note 44.

49. See supra text accompanying note 41 . 
My primary purpose in this Note is to show that Milkovich did not change libel law to include statements of "pure" opinion as potentially defamatory. My secondary purpose is to explore a more subtle issue suggested by the confusion over Milkovich: whether and when statements that can reasonably be interpreted as conveying either opinion or fact should be subject to libel suit. Specifically, in Part One I review the facts and law relevant to the Milkovich case and conclude with a discussion of why statements with especially wide variance in potential meaningsuch as "beautiful" and "ugly"-cannot reasonably be labeled "true" or "false," the core Milkovich requirenent for holding that a stateinent is potentially defamatory. In Part Two I review and critique two law review treatments and a recent state supreine court decision relying on Milkovich. Finally, in Part Three I discuss the coinplex problem of how to address statements that can be reasonably read in a bibelous or nonhibelous inanner.

\section{MILKOVICH: ITS FACTS, HoldING, AND APPLICATION}

\section{A. Factual Background}

The Milkovich case stems from events at a high school wrestling match in Maple Heights, Ohio. During a match between the Maple Heights team and rival Mentor High School, a fight broke out, leading to an investigation by the Ohio High School Athletic Association (OHSAA). Both Michael Milkovich (the coach) and H. Don Scott (the superintendent of Maple Heights Public Schools) testified at the hearing held by OHSAA. As a result of the investigation, OHSAA censured Milkovich for his role in the altercation. In addition, the Maple Heights team was placed on probation for a year and disqualified from the 1975 state wrestling tournament. ${ }^{50}$

In an attempt to restrain the OHSAA order froin taking effect, several parents and wrestlers brought suit against OHSAA in the Court of Common Pleas of Franklin County, Ohio; they alleged that the OHSAA hearing failed to provide them with adequate due process. Following testimony by Milkovich and Scott, the court agreed, and ordered that the OHSAA ruling not be put into effect. ${ }^{51}$

The next day, Ted Diadiun, a local sports columnist, published an article that severely criticized Milkovich and Scott. ${ }^{52}$ Diadiun, who attended the wrestling ineet and the OHSAA hearing, accused Milkovich

50. Milkovich, $110 \mathrm{~S}$. Ct. at 2698.

51. Id.

52. The full text of the column is as follows: 
of lying about his role in the altercation. Although Milkovich maintained that he was powerless to control the crowd and that he did nothing to encourage the fight, Diadiun said that Milkovich was "ranting"

Yesterday in the Franklin County Common Pleas Court, judge Paul Martin overturned an Ohio High School Athletic Assn. decision to suspend the Maple Heights wrestling team froin this year's state tournament.

It's not final yet-the judge granted Maple only a temporary injunction against the ruling - but unless the judge acts much more quickly than he did in this decision (he has been dehberating since a Nov. 8 hearing) the temporary injunction will allow Maple to coinpete in the tournament and inake any further discussion ineaningless.

But there is something much more important involved here than whether Maple was demied due process by the OHSAA, the basis of the temporary imjunction.

When a person takes on a job in a school, whether it be as a teacher, coach, administrator or even inaintenance worker, it is well to remember that his primary job is that of educator.

There is scarcely a person concerned with school who doesn't leave his mark in some way on the young people who pass his way-many are the lessons taken away from school by students which weren't learned from a lesson plan or out of a book. They come from personal experiences with and observations of their superiors and peers, from watching actions and reactions.

Such a lesson was learned (or relearned) yesterday by the student body of Maple Heights High School, and by anyone who attended the Maple-Mentor wrestling ineet of last Feb. 8.

A lesson, which, sadly, in view of the events of the past year, is well they learned early.

It is simply this: If you get in a jam, he your way out.

If you're successful enough, and powerful enough, and can sound sincere enough, you stand an excellent chance of making the he stand up, regardless of what really happened.

The teachers responsible were mainly head Maple wresthing coach Mike Milkovich and former superintendent of schools $H$. Donald Scott.

Last winter they were faced with a difficult situation. Milkovich's ranting from the side of the mat and egging the crowd on against the meet official and the opposing team backfired during a meet with Greater Cleveland Conference rival Metor [sic], and resulted in first the Maple Heights team, then many of the partisan crowd attacking the Mentor squad in a brawl which sent four Mentor wrestlers to the hospital.

Naturally, when Mentor protested to the goverming body of high school sports, the OHSAA, the two inen were called on the carpet to account for the incident.

But they declined to walk into the hearing and face up to their responsibilities, as one would hope a coach of Milkovich's accomplishinents and reputation would do, and one would certainly expect from a inan with the responsible poisition [sic] of superintendent of schools.

Instead they chose to come to the hearing and inisrepresent the thing that happened to the OHSAA Board of Control, atteinpting not only to convince the board of their own innocence, but, incredibly, shift the blame of the affair to Mentor.

I was among the 2,000-plns witnesses of the meet at which the trouble broke out, and I also attended the hearing before the OHSAA, so I was in a unique position of being the only non-mvolved party to observe both the ineet itself and the Milkovich-Scott version presented to the board.

Any resemblance between the two occurrances [sic] is purely coincidental.

To anyone who was at the ineet, it need ouly be said that the Maple coach's wild gestures during the events leadiug up to the brawl were passed off by the two as "shrugs," and that Milkovich claimed he was "Powerless to control the crowd" before the melee.

Fortimately, it seemed at the time, the Milkovich-Scott version of the incident presented to the board of control had enough contradictions and obvious untruths so that the six board members were able to see through it.

Probably as much in distasteful reaction to the chicanery of the two officials as in displeasure over the actual imcident, the board then voted to suspend Maple from this year's tournament and to put Maple Heights, and both Milkovich and his son, Mike Jr. (the Maple Jaycee coach), on two-year probation.

But unfortunately, by the time the hearing before Judge Marin rolled around, Milkovich and Scott apparently had their version of the incident polished and reconstructed, and the judge apparently beheved them. 
from the sidelines and "egging on" the crowd. Diadiun also said that Milkovich and Scott "polished and reconstructed" their stories about the incident prior to testifying before the Court of Common Pleas, ${ }^{53}$ and quoted the OHSAA commissioner as saying that the two inen's accounts given before the court differed from those given to the OHSAA board..$^{54}$ The headline to the column read: "Maple Beat the Law with the 'Big Lie." "Diadiun's photograph appeared below the leadline with the words "TD Says." The headline on the jump page to the column said "Diadiun Says Maple Told a Lie."s5

Both Milkovich and Scott filed defamation suits against Diadiun and the newspaper's owner, the Lorain Journal Coinpany. ${ }^{56}$ Milkovich's action, brought in the Court of Common Pleas of Lake County, Ohio, alleged that the lieadline of the column and nine passages within it "accused plaintiff of committing the crime of perjury, an indictable offense in the State of Ohio, and dannaged plaintiff directly in his life-time occupation of coach and teacher, and constituted libel per se."57

A series of court maneuvers ensued. Eventually, in Scott's case, the Ohio Supreme Court lield that the challenged passages in Diadiun's article were "constitutionally protected opinion." 58 The Ohio courts lield that this decision also determined the result in the Milkovich case. ${ }^{59}$ The U.S. Supreme Court granted ccrtiorari to consider "the Ohio courts' recognition of a constitutionally-required 'opinion' exccption to the apphication of its defaination laws." 60

"I can say that some of the stories told to the judge sounded pretty darned unfamiliar," said Dr. Harold Meyer, commissioner of the OHSAA, who attended the hearing. "It certainly sounded different from what they told us."

Nevertheless, the judge bought their story, and ruled in their favor.

Anyone who attended the meet, whether he be from Maple Heights, Mentor, or impartial observer, knows in his heart the Milkovich and Scott hed at the hearing after each having given his solemn oath to tell the truth.

But they got away with it.

Is that the kind of lesson we want our young people learning from their high school admimistrators and coaches?

I think not.

Diadiun, supra note 41 , at 35, 39, quoted in Milkovich, $110 \mathrm{~S}$. Ct. at 2698 n.2.

53. Id.

54. Id.

55. Id.

56. Milkovich, $110 \mathrm{~S}$. Ct. at 2699-700.

57. Id. at 2700 .

58. Scott v. News-Herald, 496 N.E.2d 699, 709 (Ohio 1986).

59. See Milkovich, $110 \mathrm{~S}$. Ct. at 2701.

60. Id. 


\section{B. The Opinion on Opinion: The Supreme Court's Holding}

Chief Justice Rehnquist devotes the bulk of the Milkovich opinion to reviewing the development of libel law and related constitutional doctrine. The opinion begins witl a reminder that a comınon law tort for written defamation has been available since the sixteenth century. ${ }^{61}$ Altlough the cominon law required tliat a publication be false and defamatory to state a cause of action, statements of opinion, if sufficiently damaging to imjure reputation, were still deemed to be actionable.62 Eventually, to protect public debate, the principle of "fair comment" was adopted into the common law. Fair cominent exempted from the tort of defamation expressions of opinion regarding matters of public concern and based upon "true" facts. ${ }^{63}$

As Milkovich notes, the Supreme Court imjected dramatic cliange into the comınon law of libel witl its decision in New York Times Co. v. Sullivan. ${ }^{64}$ New York Times lield that the First Amendment served to restrict state defamation law. Namely, public officials could not recover for defamatory falselioods regarding the official's public activity absent a showing of "actual malice"-reckless disregard of whether the statement was false or not. ${ }^{65}$ Curtis Publishing Co. v. Butts ${ }^{66}$ extended New York Times to imclude all public figures. ${ }^{67}$ Later, in Gertz v. Robert Welch, Inc. ${ }^{68}$ the Court lield that malice must be slown by clear and convincing proof. ${ }^{69}$ Althougli this standard was held not to control private individuals who allege defamation related to a statement of public concern, ${ }^{70}$ the Court did rule that im this circumstance tlie states must require a showmg of fault, and no pumitive or presumed damages could be awarded absent a slowing of actual malice.71

In reaching its decision in Gertz, the Court, in dictum, briefly touched on the issue of opinion: "Under the First Amendment there is no such thing as a false idea. However pernicious an opinion may seem, we depend for its correction not on the conscience of judges and juries

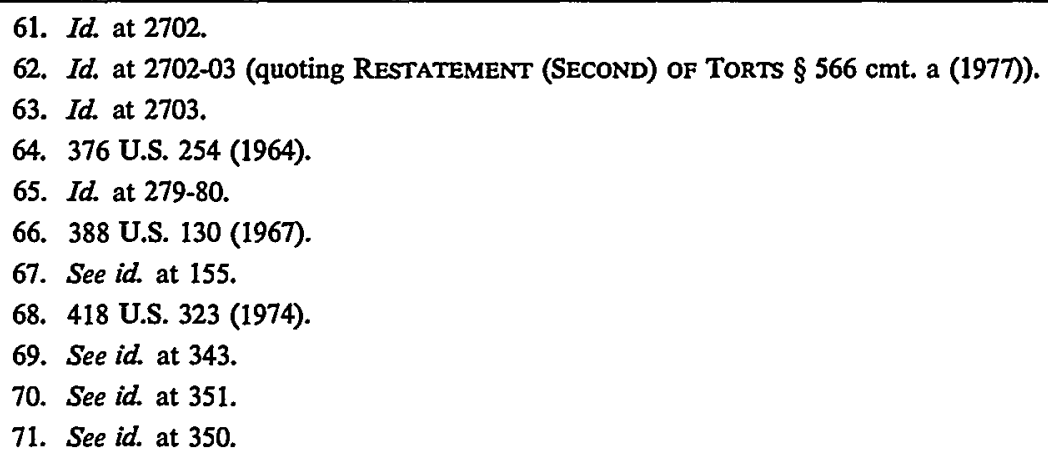


but on the competition of ideas. But there is no constitutional value in false statements of fact."72

Ultimately, im Milkovich, the Court held that although this dictum did not create a separate "wholesale" constitutional privilege for anything that might be labeled opimion, at the same time several other Supreme Court rulings, taken together, were formd already to secure constitutional protection for opimon. ${ }^{73}$ For example, in Philadelphia Newspapers, Inc. v. Hepps, ${ }^{74}$ the Court held unconstitutional the common law presumption that defamatory speech is false-at least where a media defendant publishing speech of public concern is imvolved. ${ }^{75}$ Hepps required the plaintiff to bear the burden of showing falsity, as well as fault. ${ }^{76}$ Greenbelt Cooperative Publishing Ass'n v. Bresler ${ }^{77}$ held that the First Amendment prohibits state defamation law from reaching certain types of speecl. ${ }^{78}$ In Bresler, a newspaper article quoted individuals who clraracterized a real estate developer's negotiating position as "blackmail."79 Because the article stated the underlying facts of the negotiation accurately and fully, the Court reasoned that the word "blackmail" was intended as "rhetorical hyperbole, a vigorous epithet used by those who considered [the developer's] negotiating position extremely unreasonable." 80 The Court held that the article did not imply that the developer committed the actual crime of blackmail. ${ }^{81}$ Similarly, in Hustler Magazine, Inc. v. Falwell, ${ }^{82}$ the Court lield that a vulgar advertisement parody was protected by the First Amendment as satire because the parody "could not reasonably have been interpreted as statimg actual facts about the public figure involved." 83 And in Old Dominion Branch No. 496, National Ass'n of Letter Carriers v. Austin ${ }^{84}$ the Court held that an accusation that an individual was a "traitor" due to his activity as a urion "scab" was protected speech. ${ }^{85}$ The Court said that the term "traitor"

72. Id. at 339-40 (footnote omitted).

73. See Milkovich, $110 \mathrm{~S}$. Ct. at 2705-06.

74. 475 U.S. 767 (1986).

75. See id. at 777.

76. See id. at 776.

77. 398 U.S. 6 (1970).

78. See id. at 14.

79. See id. at 13.

80. Id. at 14. 、

81. See id.

82. 485 U.S. 46 (1988).

83. Id. at 50 .

84. 418 U.S. 264 (1984).

85. See id. at 284-86. 
was, in context, used in a "loose, figurative sense," and not to be taken literally. ${ }^{86}$

Thus, although the Milkovich Court explicitly declined to recognize a separate constitutional privilege for opinion, ${ }^{87}$ under existing constitutional doctrine (including the Bresler-Letter Carriers-Falwell line of cases) the Court reaffirmed protection of "statements that cannot 'reasonably [be] interpreted as stating actual facts' about an individual." 88

Prior to Milkovich an initial inquiry in a libel suit was whether the cliallenged utterances were fact or opinion. Facts, if false and defamatory, were potentially bibelous, while opinions were protected by the First Amendinent. ${ }^{89}$ Milkovich recognized that fact and opinion inay overlap and thus requires that courts ask whether a reasonable factfinder could conclude that the expression in question iniplies an objective assertion of fact. ${ }^{90}$ If so, even phrases couclied in the langnage of opinion may be hibelous. ${ }^{91}$

But although the fornulation of the required inquiry changed, the Court left the underlying principle of the opinion privilege intact: Only assertions that "contain a provable false factual connotation" are potentially libelous.92 Even the method the Court delineated for deciding when a statement is sufficiently concrete and definable to warrant an action did not change, except in semantics, from its previous incarnations in lower courts.

As discussed earher, the Milkovich Court's "new" inethod employed three criteria in analyzing the challenged statements in the Diadiun column. ${ }^{93}$ First, whether the statements contained "the sort of loose, figurative or hyperbohic langnage which would negate the inipression that the writer was seriously maintaining" the alleged factual assertion. ${ }^{94}$ Second, whether "the general tenor of the article negate[s] this inpression."95 Fimally, whether the assertion is "sufficiently factual to be

86. See id. at 284.

87. See Milkovich v. Lorain Journal Co., 110 S. Ct. 2695, 2707 (1990).

88. Id. (quoting Falwell, 485 U.S. at 50).

89. See, e.g., Potomac Valve \& Fitting, Inc. v. Crawford Fitting Co., 829 F.2d 1280 (4th Cir. 1987); Janklow v. Newsweek, Inc., 788 F.2d 1300 (8th Cir. 1986); Ollman v. Evans, 750 F.2d 970 (D.C. Cir. 1984), cert. denied, 471 U.S. 1127 (1985).

90. See Milkovich, 110 S. Ct. at 2705-06.

91. See id. at 2706.

92. Id.

93. See supra text accompanying notes 23-25.

94. Id. at 2707.

95. Id. 
susceptible of being proved true or false."96 In sum, the Court recognized that the context, tenor, and provability of a statement must be examined to understand its reasonable interpretation.

The constitutional opinion privilege previously delineated by lower courts used the same inquiry. For instance, the test as formulated in Ollman v. Evans ${ }^{97}$ by the Court of Appeals for the District of Columbia Circuit (which was relied on by the Ohio Supreme Court in analyzing Diadiun's column ${ }^{98}$ ) states that four factors are relevant in determining if a statement is constitutionally protected opinion: (1) the specific language used; (2) whetler the statement is verifiable; (3) the general context of the statement; and (4) the broader context in which the statements appeared. ${ }^{99}$ The Milkovich Court specifically held that the Ollman court was mistaken in asserting that the Gertz dictum required a "wholesale" separate constitutional protection for "anything that miglit be labeled 'opmion." "100 But it should be apparent by even a surface comparison of the Ollman and Milkovich tests that both employ identical factors: context, tenor, and the provability of factual content. The first Ollman factor-examining the specific language used-is equivalent in meaning to examining tenor. The third and fourtli Ollman factors are explicitly concerned with context. And the second Ollman factor-verifiability-is the same as provability. To restate the comparison: The Milkovich method of excluding from hibel protection ostensible opinion statements containing "iniplied objective fact" is identical to the Ollman analysis distinguishing protected "opinion" from unprotected fact.

Two other widely used articulations of the opinion privilege are founded on common law protections of opinion, and not on the constitutional protection of opinion discussed in Ollman. Nonetheless, the tests are, like Ollman, strikingly similar to Milkovich. The totality-of-circumstances test, as articulated by the Court of Appeals for Nimth Circuit in Information Control Corp. v. Genesis One Computer Corp. ${ }^{101}$ calls for a consideration of "the statement in its totality in the context in which it

96. Id. Chief Justice Rehnquist applies these three criteria, in a distilled form, not only in analyzing the allegedly libelous newspaper column, but also in analyzing the Court's own wellknown dictum on opinion in Gertz v. Robert Welcl, Inc., 418 U.S. 323, 339-40 (1974). Rehnquist rejects the view that the dictum creates a "wholesale defamation exeinption" as being "contrary to the tenor and context of the passage" and as ignoring "the fact that expressions of 'opinion' may often inply an assertion of objective fact." Milkovich, $110 \mathrm{~S}$. Ct. at 2705 . This analysis of context, tenor, and the presence of provable factual content is identical to the tliree-step inquiry later applied in Milkovich.

97. 750 F.2d 970 (D.C. Cir. 1984), cert. denied, 471 U.S. 1127 (1985).

98. See Scott v. News-Herald, 496 N.E.2d 699, 709 (Ohio 1986).

99. Ollman, $750 \mathrm{~F} .2 \mathrm{~d}$ at 979.

100. Milkovich, $110 \mathrm{~S}$. Ct. at 2705.

101. 611 F.2d 781 (9tl1 Cir. 1980). 
was uttered or publislied" to determine if the statement is protected opinion or unprotected fact under California law. ${ }^{102}$ Furtlierniore, tenor is to be considered; as the court put it, "cautionary terms used by the person publishing the statement."103

The test set forth by the Restatement (Second) of Torts makes the same distimction as Milkovich between protected opinion and opimion that implies fact: "A defamatory commumication may consist of a stateinent in the form of an opimion, but a statement of this nature is actionable only if it implies the allegation of undisclosed defamatory facts as the basis for the opimion."104

Neither of the above non-constitutional protections of opinion statements is in any way abridged by Milkovich's requirement that only "provably false factual connotation[s]" may be libelous as determined by considering the context, tenor, and the provability of a statement. ${ }^{105}$ In fact, it may be that the Restatement approach does not provide sufficient constitutional protection for opinion in light of Milkovich. If the implied "undisclosed" defamatory fact conteinplated by the Restatement cannot "reasonably [be] interpreted as stating actual facts" 106 about an individual, as opposed to speculative "undisclosed" facts, then the Restatement approach fails to provide the constitutional protection Milkovich requires. Far froin restrictimg the opinion privilege, Milkovich might ultimately force the enlargement of the Restatement approacli.

What the Supreme Court rejected in Milkovich was an entirely separate constitutional privilege for any statement couched in the language of opinion. Gertz was not intended "to create a wholesale defamation exemption for anything that might be labeled 'opinion." "107 But, as the above examples of the "old" opimion standard illustrate, the preMilkovich opimion privilege never created such a wholesale exemption. Milkovich removed nothing from existing doctrime by refusing to find content in the Gertz dictum.

Chief Justice Rehnquist used the following as an illustration of the implied fact/protected opinion distinction: "[U]nlike tlie statement 'In my opinion Mayor Jones is a liar,' the statement, 'In my opinion Mayor Jones sliows his abysmal ignorance by accepting the teachings of Marx and Lenin,' would not be actionable."108 Presumably, the first example is

102. See id. at 784.

103. Id.

104. Restatement (SECOND) OF TORTS § 566 (1977).

105. Milkovich, 110 S. Ct. at 2706.

106. Id. (emphasis added) (quoting Hustler Magazine, Inc. v. Falwell, 485 U.S. 46, 50 (1988)).

107. Id. at 2705.

108. Id. 
one of "couched" opinion, focusing on the telling of truths or untruths, as might be determined in a court action for perjury. The second example is one of "pure" opinion, focusing on the phrase "abysmal ignorance," presumably because a plamtiff could not "prove" if by accepting Marx and Lenin the plaimtiff showed ignorance or enlightenment.

This particular hypothetical, however, is only helpful to a point, as varying contexts for the stateinents could be imagined so as to give the hypothetical opposing interpretations. For example, if the statement "Mayor Jones said he never stole from the public treasury" precedes the sentence "In my opinion, Mayor Jones is a har," then the interpretative focus imagined by the Chief Justice is clear: One would ask if there is a factual basis for the speaker's assertion that the Mayor stole, despite the "couching" of the accusation in terms of opimion. But if the statement "Mayor Jones says he no longer accepts the teachings of Marx" precedes the sentence "In my opimion, Mayor Jones is a har," then the hypothetical is turned on its end. The speaker in this second example is asserting that Mayor Jones still accepts the teachings of Marx, despite his statement to the contrary. Read this way, Mayor Jones is a "har" because he says he does not accept what he really does accept, and the speaker's comment is an assertion of his opimon about the mayor's beliefs. The speaker might assert, for example, that the Mayor's support for pubhic health care proves that the Mayor is really still a Marxist. The Mayor might assert that he abandoned Marxism years ago, and his support for public health care just makes him a hiberal. Neither the speaker nor the Mayor could prove the falsity of this alleged "lie," although the hypothetical, because it is not grounded in context, might be misread to iniply otherwise.

\section{Which Lie? Applying the Law to the Facts}

To get a firmer grasp of the Court's imtended use of the Milkovich test, one should pay particular attention to the Chief Justices's specific instructions as to how, on remand, the Ohio court should test Diadiun's stateinent. The crucial question in understanding the specific instruction is: What lie is being referred to when the Court says Diadiun's accusation of a "lie" told by Milkovich is actionable? Although tlie column discusses two distinct "lies," the Court's specific instruction in testing the statement shows that tlie Court only intended to hold one of these accused "lies" as potentially actionable. The first, more obvious "lie" is Diadiun's rejection of Milkoviclı's cliaracterization of Milkoviclı's beliavior during the altercation. This is the question of whetlier Milkovich "shrugged" or "ranted," whether he was "powerless" to control the crowd, or whetlier lie was "egging on" the crowd. The second "lie" 
Milkovich is accused of telling is his alleged change in testimony from the first to the second hearing. Chief Justice Rehnquist's specific instructions to test the alleged defamation by comparing the two hearing transcripts ${ }^{109}$ deinonstrates that only this second alleged "lie" is to be considered as a potentially actionable statement. To gain a better understanding of why only the second "lie" is held actionable, it is necessary to examine the Diadiun column in fuller context.

On the night of the altercation, in front of a crowd of fans, it is undisputed that Michael Milkovich served as the wrestling coach to Maple Heights. ${ }^{110}$ It is also undisputed that during the natch Milkovich made statements and gestures that were audible and visible to the crowd.111 But the nature of the remarks, and any effect the reinarks might have had in inciting the altercation, are very inuch im dispute.

In his column, Diadiun described the events at the ineet, which he attended, as follows: "Milkovich's ranting from the side of the n1at and egging the crowd on against the ineet official and the opposing tean backfired during a nieet with Greater Cleveland Conference rival Metor (sic), and resulted in first the Maple Heights team, then many of the partisan crowd attacking the Mentor squad in a brawl which sent four Mentor wrestlers to the hospital."112 That Milkovich and Scott vehenently disagreed with Diadiun's assessinent of the incident is made clear by Diadiun's column itself: "the Maple coach's wild gestures during the events leading up to the brawl were passed off by the two as 'shrugs,' and that Milkovich claimed he was '[p]owerless to control the crowd' before the inelee."113 Diadiun continued: "Fortunately, it seemed at the time, the Milkovich-Scott version presented to the [OHSAA] board of control had enough contradictions and obvious untruths so that the six board niembers were able to see through it." 114

Diadiun's first accusation against Milkovich and Scott is that they misrepresented the events at the inatch to the OHSAA board: "Instead they chose to come to the hearing and misrepresent the things that happened to the OHSAA Board of Control, attempting not only to convince the board of their own mnocence, but, incredibly, shift the blame of the affair to Mentor."115

109. See id. at 2707.

110. Id. at 2698.

111. See id.

112. See Diadiun, supra note 41 , at 39.

113. $I d$.

114. Id.

115. Id. 
However, the above passage was not listed in Milkovich's libel suit as defamatory. Instead, Milkovich identified the headline and the following nine passages from the column as defamatory:

[A] lesson was learned (or relearned) yesterday by the student body of Maple Heights High School, and by anyone who attended the MapleMentor wrestling meet of last Feb. 8.

A lesson which, sadly, in view of the events of the past year, is weil they learned early.

It is simply this: If you get in a jam, he your way out.

If you're successful enough, and powerful enough, and can sound sincere enough, you stand an excellent chance of making the he stand up, regardless of what really happened.

The teachers responsible were mainly head Maple wrestling coach Mike Milkovich and former superimtendent of schools $\mathrm{H}$. Donald Scott.

Anyone who attended the meet, whether he be from Maple Heights, Mentor, or impartial observer, knows in his heart that Milkovich and Scott hed at the hearing after each having given his solemn oath to tell the truth.

But they got away with it. Is that the kind of lesson we want our young people learning from their high school administrators and coaches?

I think not. ${ }^{116}$

Not clear from any of the alleged defamatory statements quoted above is the exact content of the "lie." Because truth is an absolute defense in a hibel suit, ${ }^{117}$ if Milkovich really did he in court, no legal action would be possible, regardless of the damage to his reputation. As fundainental a question as "what was the he" might seem to the disposition of the case, Chief Justice Relinquist never answers it directly. However, the intended content of the "lie" is made plain by Relınquist's specified inethod for testing the "lie." Toward the conclusion of the majority opinion, Rehnquist states that "[a] determination of whetlier petitioner lied in this instance can be made on a core of objective evidence by comparing, inter alia, -petitioner's testiniony before the OHSAA board with his subsequent testimony before the trial court."118 This specified inethod narrowly focuses on the change in testimony that Diadiun alleges took place before the Court of Common Pleas.

116. $I d$.

117. See Philadelphia Newspapers, Inc. v. Hepps, 475 U.S. 767, 776 (1986) (fashioning "a constitutional requirement that the plaintiff bear the burden of showing falsity, as well as fault, before recovering damages" against a media defendant for speech of public concern).

118. Milkovich, $110 \mathrm{~S}$. Ct. at 2707. 
The other possible interpretation of the alleged "he" is a reference to Milkovich's characterization of the fight. This interpretation is rationally based on the language of the column. Recall that one of the passages Milkovich identified as defamatory said that "[a]nyone who attended the meet, whether he be from Maple Heights, Mentor, or impartial observer, knows in his heart that Milkovich and Scott lied at the [Court of Common Pleas] hearing after each having given his solemn oath to tell the truth." 119 One understanding of the sentence is that "anyone" at the match saw and heard what happened; at the Court of Common Pleas liearing, Milkoviclı and Scott described the events in a way that Diadiun behieved "anyone" at the match would find inconsistent with what actually happened. Namely, Diadiun behieved that Milkovich encouraged the fight, while Milkovich and Scott demed this. This "he," then, is Milkovich's statement that he did not encourage the altercation.

But considering the wide variance in meaning a reasonable juror might give to the definition of enticing violence in a crowd of wrestling fans, holding such a statement as potentially defamatory would seem to violate Milkovich's maxim that only statements capable of being proven true or false may be considered libelous. Indeed, requiring jurors or a court to resolve such an issue as "fact" is wholly inconsistent with the Court's specific instruction (to compare Milkovich's testimony from the OHSAA hearing to the court hearing) regarding the ultimate resolution of the Milkovich defaination action. How could comparing transcripts of Milkovich's own testimony determine whether his characterization of events at the wrestling inatch was accurate? After all, even if he wildly lied in both instances, his own testimony would not be likely to reveal anything but internal inconsistencies-hardly an "objective" evaluation of what transpired at the match. This cannot be the inquiry the Court calls for because it is not resolvable by a "core of objective evidence." 120

Instead, Chief Justice Rehnquist's analysis leads exclusively to a focus on the question of the change in testimony from the OHSAA hearing to the court hearing. The paragraphs preceding and following the sentence, "[a]nyone who attended the meet," put this focus into context.

But unfortunately, by the time the hearing before Judge Martin rolled around, Milkovich and Scott apparently had their version of the incident polished and reconstructed, and the judge apparently believed thein.

"I can say that some of the stories told to the judge sounded pretty darned unfamiliar," said Dr. Harold Meyer, coinınissioner of

119. Diadiun, supra note 41 , at 39 (emphasis added).

120. Milkovich, 110 S. Ct. at 2707. 
the OHSAA, who attended the hearing. "It certainly sounded different from what they told us."

Nevertheless, the judge bought their story, and ruled in their favor.

Anyone who attended the meet, whether he be from Maple Heights, Mentor, or impartial observer, knows in his heart that Milkovich and Scott lied at the hearing after each having given his solemn oath to tell the truth.

But they got away with it. 121

The only way the Court's test of comparing Milkovich's testimony at the hearings is coherent is if the "he" referred to is the "polishing and reconstructing" of the stories. The Court must have this, and this "he" alone, in mind or it could not have stated so directly and concisely just what the lower court was to do in assessing the alleged defamatory statements: relying on a "core of objective evidence," compare Milkovich's testimony at the two hearings. ${ }^{122}$

It might be argued that the bulk of Diadiun's column does not focus on this "he." Diadiun demonstrates much more concern in the column with Milkovich's characterization of his behavior at the wrestling match than with Milkovich's alleged change in testimony. One should keep im mind, however, that just because one potentially libelous statement or imphed fact in a column is among many others does not necessitate that all of the stateinents or implied facts in the column be considered potentially hibelous. Making such a blanket assumption defies logic, and perhaps more to the point, defies the exphicit standard in Milkovich requiring that for any statement to be considered hbelous it must reasonably be provable as true or false. For this standard to function, each allegedly bibelous statement in an article, and each allegedly libelous imphied fact, must be examined separately.

Applying this statement-by-statement examination to the Diadiun column reveals only a single challenged accusation that might be considered hibelous. In his column, Diadiun states that "Milkovich and Scott apparently had their version of the incident polished and reconstructed."123 The accusation is somewhat tempered by the use of the word "apparently." However, without the word "apparently," the factual assertion of the sentence is direct: There was some change in testimony froin the first OHSAA hearing to the second court hearing. Thus, the word "apparently" serves to "couch" the sentence in a term of opinion. The "couclied" accusation is supported by a quotation from Dr.

121. Diadiun, supra note 41 , at 39.

122. Milkovich, 110 S. Ct. at 2707.

123. Diadiun, supra note 41 , at 39 (emphasis added). 
Meyer, and is implicitly repeated, this time without the word "apparently," in the following sentence, when Diadiun states that the judge "bought their story." 124

The use of Dr. Meyer's quotation, the implicit repetition of the accusation in the following sentence, and Diadiun's immediate juxtaposition of the accusation against the charge of violating a solemn oath to tell the truth, inake plain that Diadiun presents his assertion without intending the reader to question its veracity. The Court inust be referring to this assertion when it declines to afford Diadiun's column full constitutional protection.

In his dissent, Justice Breunan disagrees that this assertion of a change in testimony should be considered potentially libelous. ${ }^{125}$ Brennan argues that the use of the "cautionary term 'apparently" " is an "unmistakable sign that Diadiun did not know what Milkovich had actually said in court."126 Justice Brennan also argues that because the piece is a signed editorial with a photograph of the author, the reader is signaled that the story is not to be taken as fact. And he asserts that the tone "is point, exaggerated and heavily laden with enotional rhetoric and moral outrage," thus negating the impression that the article is factual, 127

Whether or not one agrees with Justice Brennan about the significance of the "couched" term "apparently," it is important to recognize that the debate within the Milkovich Court does not extend to the "pure" statements of opimion found in the Diadiun column. Nowhere does Milkovich discuss sending to the jury questions regarding the characterization of the fight. The misunderstanding some commentators have demonstrated to the contrary is explained by the structure of the Diadiun column. Certain passages of the column vagnely make reference to a "lie" without specifying the nature of the accusation.

For example, although the implied act of perjury 128 recognized by Chief Justice Relınquist is the change in the story itself, the "lie" in the

124. Id.

125. Milkovich, $110 \mathrm{~S}$. Ct. at 2712 (Brennan, J., dissenting).

126. Id.

127. Id.

128. Diadiun never actually uses the word perjury in his column. He states "that Milkovich and Scott lied at the hearing after each having given his solemn oath to tell the truth." Diadiun, supra note 41 , at 39 . Of course, this accusation is very close to a charge of perjury. The term was used by the petitioner in his complaint and accepted by Rehnquist without discussion of the possible distinction between it and lying. But there is a possible distinction, resting precisely on the contextual difference between the use of the word "he" as a term of dishonor and the use of the word as a term with legal meaning.

In the context of Diadiun's exhortation of a "lesson" to be learned by high school students, Diadiun is not so much concerned with (or even knowledgeable about) the legal requirements of perjury as he is with the question of honor and doing the right thing-even if (or despite the fact 
alleged defamatory sentence beginning "[a]nyone who attended the meet" also refers to Milkovich's general characterization of the meet. As discussed earlier, the use of the phrase "[a]nyone who attended the meet" imphies that those familiar with events at the meet know that Milkovich's characterization of his behavior was a "lie." 129 Those at the meet would have no knowledge of Milkovich's alleged change in testimony. However, in context, the sentence follows directly froin Diadiun's discussion of the alleged alteration in testimony. The "he," therefore, can also be read to refer to the change in story. Milkovich teaches that the corresponding "opinion" content of this sentence does not prevent the implied "fact" content from being challenged. The presence of inıphied "fact" content in the passage, however, does not indicate that the "pure" opinion content of the stateinent inay also be challenged.

Further complicating the inatter is another challenged section of the column referring to a "he." This section is also as equally oriented toward the description of the fight as it is to a comparison of the testiniony from the first to the second hearing. The section states: "If you're successful enougl, and powerful enough, and can sound sincere enough, you stand an excellent chance of making the lie stand up, regardless of what really happened." The immediately following paragraphs then turn to the events of the altercation. The statement "what really happened" might refer to the cliange in story from the first to the second hearing. But another reading, given the immediate juxtaposition against a description of events at the ineet, is a reference to "what really happened" at the wrestling inatch. Despite the two possible interpretations, the Court could not have ineant to hold the latter interpretation out as potentially defamatory because the Court's requirement of a "core of objective" evidence would not allow for it.

The constitutional requirements reiterated by Milkovich allow for ouly one possibility in analyzing the potential defamatory content of the above aunbiguous sentences: The imphied "fact" content of the passages

that) no damaging legal consequences will result from doing the wrong thing. This is how Diadiun closes his column: "Is that the kind of lesson we want our young people learning from their high school administrators and coaches? I think not." Id. This is not the tenor of a prosecutor seeking a perjury indictment. Yet this is the standard to which Rehnquist assumes Diadiun should be held. Instead, the Court should hold Diadiun to the standard he sets with his own words. Diadiun states that Milkovich polished and reconstructed his story, and that this change constituted a violation of Milkovich's oath to tell the truth. The factual question on remand should be whether the comparison of the transcripts reveals that Milkovich polished and reconstructed his story to a degree that would lead a reasonable juror to believe that he violated his oath to tell the truth. Whether such a reconstruction could actually lead to a conviction of perjury only clouds the issue. It should be clear, however, that even Rehnquist's tacit assumption of a "perjury" accusation does not implicate a "pure" statement of opinion as potentially defamatory.

129. See supra text aecompanying note 119 . 
may be scrutinized, but the "pure" opinion content must be left undisturbed. The presence of both types of content in a single passage should not be understood to imdicate that "pure" opinion assertions "lose" their privilege. ${ }^{130}$

\section{The Beautiful and the Ugly: Why Different Words Require Different Constitutional Protection}

The Milkovich Court's focus on "a core of objective evidence" makes it more straightforward for Michael Milkovich to prove his case. He need only demonstrate that his testiniony at the two hearings, as recorded by transcript, was not sufficiently different to justify Diadiun's accusation that it constituted a "lie." But the Court's focus also makes it easier for Diadiun to disprove Milkovich's case. Small but significant changes in his testinoony might be found reasonably to justify characterization of the testiniony as a he.

By contrast, if the court forced Milkovich to disprove Diadiun's account of the fight, then it would require the parties to enter into an unresolvable quagmire because of the linguistic difficulties associated with confining the meaning of the phrases that Diadiun used to suggest Milkovich encouraged the fight. 131

To reach the conclusion that these statements are not susceptible to a libel suit because they are not "factual," one must accept the proposition that even words with stable meanings can have a wide variance in interpretation depending on context and tenor. The Milkovich Court, by requiring an examination of context and tenor, recoguizes that the meaning of words is always subject to interpretation depending on context. Some words and phrases have a greater potential for variance, as they are commonly used, than others. For instance, the words "beautiful" and "ugly" are usually subject to much greater variance in meaning than the words "open" and "shut." Words, phrases, and statements with the potential for especially wide variance in interpretation are bad candidates for libel suits because the plaintiff or defendant will be unable to "prove" as true or false any one interpretation.

Roughly speaking, those statements with the potential for wide variance in interpretation are "opinion," while those statements with the least potential for reasonable imterpretation are "fact." Because context results in a inyriad of interpretative possibilities, a set determination of

130. The problem of what to do with a statement that contains both constitutionally protected opinion and factual content is more fully discussed in Part Three.

131. These phrases were "ranting from the side of the mat," "egging the crowd on," "wild gestures," and the statement that this behavior "backfired . . . and resulted . . . in a brawl." Diadiun, supra note 41 , at 39 . 
which words are fact and which words are opinion is impossible. In a constitutional setting, however, the determinative factor is reasonableness. Thus, "facts" are contained in those statements that in context have a suitably narrow range of interpretation such that juries can reasonably decide if the meaning conveyed by the stateinent corresponds as "true" or "false" to a state of events.

Absent context, there is no formula for deciding which phrases are sufficiently limited in meaning to be the potential subject of a libel suit. Rather, as the Court indicates in Milkovich, the context, tenor, and provability of each cliallenged statement inust always be examined. ${ }^{132}$ Domg just that witl the phrases "ranting," "egging on," "wild gestures," and the core assertion thiat all of these things "resulted" in the "brawl," does not yield nearly the requisite level of "objective" fact tliat the Court mandates. If, for instance, the coach said, "Go get "em" in a loud voice, does this constitute "egging on"? What if the coach said that he always yells "Go get 'em" before a meet and there had never been a fight before? What if Diadiun could call as a witness a sixteen-year-old fan who would testify that upon liearing the coach yell "Go get "eln" lie felt an irresistible urge to pummel the opposing team's ineinbers? What if the coach said he always raised his anns as signals to his players? What if Diadiun simcerely believed that waving one's arins around is the same as making "wild gestures"?

Or, to go to the lieart of the inatter, who can conclusively say wliat action or events led to the altercation? Where a series of underlying facts are imdisputed and made plain to the reader, and the conflict revolves around an evaluation of these underlying facts, there is no "objective" method of proving the evaluation riglit or wrong. The Milkovich Court states that where "tlie speaker states the facts upon whicli lie bases his opimion, if tlrose facts are eitlier incorrect or incoinplete, or his assessinent of thein is erroneous, the stateinent may still imply a false assertion of fact."133 Yet the presence of an "erroneous" assessment is not sufficient to trigger a potential libel action, unless the "erroneous" assessment implies the existence of facts thiat turn out to be false. The question of the "truthfuhress" of tlie evaluation itself is one of reasonableness in interpretation subject to differences im assessment from individual to individual. If no "false" statement of fact is implied by an evaluative statement, even if the speaker's assessment is "erroneous" in tlie eyes of a court, the statement cannot constitutionally be considered libel.

132. See Milkovich, $110 \mathrm{~S}$. Ct. at 2707.

133. Id. at 2706. 
The characterization of events leading up to the altercation in Milkovich is just such an individual evaluation. Dozens of witnesses saw Milkovich's gestures and heard his words. One might imagine that the event was videotaped. Even with such strong evidence of what occurred at the match, it reinains an individual judginent whether or not the net effect of Milkovich's gestures and words was to encourage the altercation. The opmion content of this judgunent is akin to a critic calling a singer's voice "flat," or a restaurant reviewer labeling soup "lousy."134 There is no "right" or "wrong" answer to such an individual judginent, and Milkovich wisely leaves wide freedom for imdividuals to make evaluative statements not provable as "true" or "false."

\section{BAD APPLes: Misuses of MILKovich}

Failure to recognize that the Milkovich holding only applies to those statements that can be reasonably described as carrying direct or implied fact content has already led to significant confusion. Two law review treatments of Milkovich and a recent decision by the Wyoming Supreme Court are illustrative. ${ }^{135}$

Professor Antliony D'Amato, in his essay Harmful Speech and the Culture of Indeterminacy, explains at length how "the core of objective evidence" required by Milkovich cannot determine whether Milkovicli's characterization of the figlit was, in fact, a "lie."136 Yet D'Amato does not recognize the necessary implication of his observation: The Supreme Court did not intend the lower court, on remand, to reach such a determination.

D'Amato's apparent assumption is that the lolding apphes to all statements in the column and to all levels of imterpretation of all the statements. He chooses as an exainple of the scope of Milkovich the column's "shrugging allegation," and he demonstrates (successfully I beheve) that the opinion content of a charge of "shrugging" versus "ranting" does not leave the statement open to factual analysis. ${ }^{137}$

D'Amato writes that although Milkovich "is in the best position to know what lie is doing," Diadiun might have interpreted Milkovich's behavior differently from the way im which Milkovich interpreted his

134. For a more rigorous analysis of why language can mean different things at different times, see WrTtgenstein, supra note 1, and J.L. Austin, How To Do ThINGS WITH Words 143 (2d ed. 1975) ("It is essential to realize that 'true' and 'false' hike 'free' and 'unfree,' do not stand for anything sunple at all; but only for a general dimension of being a right or proper thing to say as opposed to a wrong thing, in these circumstances, to this audience, for these purposes and with these intentions.").

135. See D'Amato, supra note 3; Stern, supra note 3; Spence v. Flynt, 816 P.2d 771 (Wyo. 1991).

136. See D'Amato, supra note 3, at 339.

137. See id. at 346 . 
Own behavior. ${ }^{138}$ Although "Milkovich may well have thought he was shrugging [and], may well have tried to shrug . . . perhaps Diadiun's statement should be imterpreted only as saying, 'I saw Milkovich rantimg; he later told the court he was shrugging, but it sure looked like ranting to me." "139 According to D'Amato, the distinction between actor and observer necessarily signals to a reader that the observer's comments about the actor are not based on the actor's internal behefs. "[W] cannot credibly conclude that Diadiun's statement that Milkovich was lying was anything other than an abbreviated and hyperbolic way of saying, "I saw him rantimg even though . . . he may have thought he was only shrugging," " D'Amato asserts. ${ }^{140}$ Thus, neither Diadiun's nor Milkovich's opposing interpretations of the same event is provable as "false," and a descriptive statement regarding the event could only be "opinion."

D'Amato analyzes the fact/opinion distinction in Diadiun's column cogently, but despite this he does not realize which passages in Diadiun's column the Court imstructed the lower court to assess. For instance, D'Amato recognizes that if Milkovich consistently hed from the first to the second hearing, then a comparison of the two transcripts would not reveal the "he."141 D'Amato apparently has in mind the "he" concerning the fight. But D'Amato does not realize that if Milkovich's testimony was consistent, then Diadiun's column was inaceurate in asserting that Milkovich "pohshed and reconstructed" his testiniony, another aspect of the "lie" accusation. And this assertion could easily be tested by comparing the testiniony at the two hearings.

D'Amato's overinclusive reading of the range of statements iniphcated by Milkovich leads him to conclude:

On remand, the Supreme Court gave Milkovich no guidance. He has no way to prove he was telling the truth to the trial judge. Similarly, the Court gave Diadiun no guidance. All he can do is repeat his story that he saw Milkovich ranting, not shruggirg, and that he said so im his column. ${ }^{142}$

D'Amato asks rlietorically: "And is not the reporter entitled to state his own opinion that Milkovich hed both to the Board and to the common pleas court when Milkovich told them that he had only shrugged?"143 D'Amato beheves Milkovich answers this question in the negative. But a closer look at Milkovich reveals the answer to be "yes."

138. Id. at $345-46$.

139. Id. at 345 .

140. Id. at $345-46$.

141. See id. at 341.

142. Id. (footnote omitted).

143. Id. at 341-42. 
Such an opinion cannot be proven true or false from a "core of objective evidence" and thus is constitutionally protected from defamation actions.

Professor Nat Stern, in his article Defamation, Epistemology, and the Erosion (But Not Destruction) of the Opinion Privilege, states that Milkovich represents an "ominous" tilting toward "the less skeptical" of the methods previously used by lower courts to determine a statement's factual content. 144 Despite this assertion, Stern recognizes that the Milkovich Court did not change the Court's previous constitutional standard. He writes, "the Court has jettisoned the terminology rather than the essence of the fact-opinion distimction."145 Stern's concern, then, stems not from any change in the law, but from what he calls "the Court's preference for a particular way of reading the facts"146 of the Diadiun column. In fact, it is Stern's apparent misreading of the Court's application of the law to the Diadiun column that gives rise to Stern's assertion that "Milkovich may provide inomentum to a more subtle expansion of the range of expression subject to successful defamation suits." 147

Professor Steru seems to operate under much the same assumption as D'Amato. Stern argues that "having conceded that [Diadiun's] firsthand knowledge was limited to observations made at the wrestling meet and the OHSAA hearing, Diadiun could also have been viewed simply as offering the conclusion-'conjecture'- that he had drawn from the information set forth in his column."148 Instead, Stern states that Diadiun is "held accountable for the most severe construction that could be placed on [his] words." 149 Stern does not specify the meaning of "severe construction" that he has in mind, but from his mention of Diadiun's firsthand observations at the meet, Stern miphes that the "severe construction" to which Diadiun will be held "accountable" relates to Diadiun's characterization of the fight at the wrestling meet. However, this is not a construction that the Supreme Court's instruction perinits-at least in so far as identifying the meaning of the challenged Diadiun passage that may properly be the subject of a hbel suit.

Stern goes on to say that courts concluding that a statement has factual content "bear a special responsibility to delineate precisely"150 the nature of the facts. He asserts that Milkovich fails "to confine more

144. See Stern, supra note 3, at 595.

145. Id. at 614 .

146. Id. at 615 .

147. Id. at 616 .

148. Id. at 623 .

149. Id.

150. Id. at 624 . 
clearly the universe of permissible implications [giving] unfortunate encouragement to judicial inclinations to find implied factual assertions on an unpredictable basis."151 Stern's concern is understandable. After all, Chief Justice Rehnquist does not go through the allegedly defamatory statements line by line to separate the provable facts from the protected opinions. Ultimately, however, it is not an exceedingly difficult task to make one's own delineation given the Court's precisely articulated inethod of applying the Milkovich holding to the facts of the case. To the extent that Stern suggests that the Court's articulated method is capable of yielding anything more than a demonstration of whether Milkovich changed his testimony, then Stern is mistaken and he may mislead others into beheving that Milkovich encourages libel suits based on statements of "pure" opimion.

Stern is also mistaken when he argues that "[p]erhaps the most ominous aspect" of Milkovich is the Court's "apparent enthusiastic einbrace" of the Restatement. ${ }^{152}$ Stern cites a section of the Court's opinion that details the historical background of libel to justify his conclusions. ${ }^{153}$ Altlough the section does extensively quote the Restatement, the Court uses the Restatement liere only to summarize the historical development of the common law. ${ }^{154}$ Subsequently, the Court states that "[i]t is worthy of note thiat at common law" the principle of fair comment did not protect false stateinents of fact, quoting the Restatement's summation of the common law. ${ }^{155}$ Neither of these instances suggests that the Court is "enthusiastic[ally] einbrac[ing]" the common law as representative of the state of constitutional doctrine. ${ }^{156}$ Quite the contrary. Immediately following the historical discussion of the Restatement, the Milkovich Court states that, since 1964, the Supreme Court lias "placed [constitutional] limits on the application of the state law of defamation."157 Stern's critique of the Restatement approach then, is not a critique of Milkovich. As previously argued, Milkovich miglit actually necessitate the enlargement of the Restatement protection of opmion stateinents. 158

Perhaps the most troubling example of a misreading of Milkovich is found in a recent Wyommg Supreine Court decision, Spence v. Flynt. ${ }^{159}$ Spence involved a defamation action brought by attorney Gerry Spence

151. Id. at 623-24.

152. Id. at 617 .

153. See id. at 617 (citing Milkovich, $110 \mathrm{~S}$. Ct. at 2702-03).

154. See Milkovich, 110 S. Ct. at 2702-03.

155. Id. at 2706.

156. See Stern, supra note 3, at 617.

157. Id. at 2703.

158. See supra text accompanying notes 105-06.

159. 816 P.2d 771 (Wyo. 1991). 
against Hustler magazime. Hustler featured a story about Spence in its July 1985 issue. The story attacked Spence, and in the course of the attack made Spence the subject of a great many vulgarities. ${ }^{160}$

In its opinion, the Wyoming Supreme Court states that "Milkovich laid to rest the absurd notion that anything published that is couched in opinion language cannot be defaination ...."161 The Spence court then states that Milkovich "affords legal immunity for the honest expression of opinion on matters of legitimate public interest when based upon a true or privileged statement of fact"162 - a holding Spence asserts Milkovich justifies based on "fair comment" doctrine. 163

Spence represents such a serious inisreading of Milkovich that it is difficult to choose where to begin a rebuttal, but let ine start with a refutation of the Wyoming court's description of the Milkovich holding. First, Chief Justice Rehnquist in no way rehes on the fair comment doctrine, which is part of common law, as a basis for the Milkovich holding. Although "fair comment" is mentioned as part of the historical discussion of defaination, ${ }^{164}$ the Court entirely rehes on constitutional decisions m ruling that statements of public concern inay not be the subject of defaination unless they contain "a provably false factual connotation."165 Thus, before the Spence court can assert that the Hustler stateinent is defamatory, it must conclude that the statement can be proven true or false. The common law presuniption that defainatory speech is false was ruled unconstitutional by Hepps, as reiterated by Milkovich. ${ }^{166}$

The Spence court also is mistaken in stating that Milkovich only protects an "honest expression of opinion" based on "true" facts. The Spence court seeins to imply that dishonest expressions of opinion based on true facts are not protected, although the court does not atteinpt to explain just how an opinion can be dishonest if it is based exclusively on "true" facts, and does not, by virtue of its evaluative nature, imply any additional untrue facts. Milkovich leaves no rooin for the possibility that an opinion that does not in some manner imply untrue facts can be considered libelous, even if the lower court beheves the opmion not to be "honest."

Most critically, the Spence court fails to mention the Milkovich requirement that a statement be provably false before it can be libelous.

160. For the full text of the story, see id. at 773 .

161. Id. at 775 .

162. Id.

163. Id. at 774-75.

164. See Milkovich, 110 S. Ct. at 2703.

165. Id. at 2706.

166. Id. at 2704 (quoting Hepps, 475 U.S. at 777). 
Such an inquiry reveals that none of the direct or imphed factual (as opposed to opimon) assertions in the Hustler story could hold Spence up to "hatred, contempt, or ridicule."167 A review of the Hustler story will make this plain.

First, the story identifies lawyers as a parasitic group "eager to sell out their personal values, truth, justice and our hard-won freedoins for a chance to fatten their wallets." 168 Next, the story identifies Spence as a lawyer and notes that although he holds himself out as a "country lawyer" he is actually rich and owns a large ranch. ${ }^{169}$ The column then states that Hustler is among those Spence has sued and that he is seeking $\$ 150$ million from the inagazine on behalf of radical feminist Andrea Dworkin. ${ }^{170}$ All of the above is accomplished with substantially more vulgarity than represented here, but not one of the essential opinions or facts, imphed or directly stated, is oinitted. Isolating just the facts, the article states that Spence portrays himself as a hittle guy, but he is in fact wealthy and is suing Hustler on behalf of Andrea Dworkin. These factual assertions, however, are obviously not what bothers Spence. First, Spence would probably concede that all of the above facts are true; even if he did not, the portrayal of one's self as a country lawyer while being rich and suing Hustler magazine on behalf of a well-known feminist hardly seems the stuff that holds one up to "hatred, contempt, or ridicule." Rather, the defamation action seems motivated by the story's vulgarly presented accusations that Spence is greedy and has sold out his "personal values, truth, justice and our-hard-won freedoms" for the pursuit of large suins of money. ${ }^{171}$ It should be obvious that there is no "fact" at stake in these accusations that can be decided by a "core of objective evidence." 172 No judge or jury can decide as a factual inatter if a lawyer's pursuit of a $\$ 150$ million verdict makes the lawyer greedy or a sell-out. Milkovich forbids such an mquiry as a matter of constitutional law.

Furthermore, Milkovich im. no way suggests that vulgarity, by itself, can be the subject of a defamation action. The opposite is true. Because vulgarity, by itself, typically has no provable fact content, but instead represents ouly an individual's personal judgment about another, Milkovich generally protects such statements from defamation actions. ${ }^{173}$

167. See Spence, 816 P.2d at 776.

168. Id. at 772 .

169. See id. at 773 .

170. See id.

171. See id.

172. Milkovich, $110 \mathrm{~S}$. Ct. at 2707.

173. The Restatement (Second) of Torts takes the position that vulgarity ordinarily cannot be reasonably understood as asserting a fact. See REsTATEMENT (SECOND) OF TORTS $\$ 566 \mathrm{cmt}$. e 


\section{Roads Not Traveled: The Possibility of Multiple REASONABLE INTERPRETATIONS}

The confusion generated by Milkovich leads to a related question: What if the same sentence can be read as conveying fact and opinion simultaneously, or as conveying only opinion, or as conveying only fact, depending on what interpretative lens is used in the reading? Consider the following statement: "While Jack's wife was away on business, he slept over at Marie's house." Suppose the statement is made in the context of a discussion of Marie's kindness to her friends. Where either an exclusively non-hibelous interpretation (e.g., the hiteral meaning of the words) or a hibelous interpretation (e.g., that Marie and Jack engaged in an extramarital affair) is reasonable, I argue in this Part that the exclusively non-ibelous imterpretation shonld preclude an action for libel, even if a reader later infers defamatory meaning.

The question unight be viewed as follows: Does the presence of a reasonable, exclusively non-libelous interpretation (that is, an interpretation in which a potentially bibelous meaning need not be part of a reasonable reader's interpretation) of a statement preclude the stateinent froin being held defamatory? I think so, but the demonstration of this might not be obvious, especially where a reasonable hibelous interpretation also seeins to be present. This Part offers both a First Amendment and a tort method for analyzing statements with more than one reasonable interpretation.

The analytical difficnlty here stems from a linguistic difficultymore than one interpretation of a statement can be reasonable. ${ }^{174}$ For the purposes of a libel action based on a media account of a matter of public concern, however, the way out of this difficulty is contained by assigned burdens of proof, as necessitated by the First Amendinent. Recall that the Supreme Court has held that the First Amendment requires . that the plaintiff bear the burden of showing falsity, as well as fault, before damages can be recovered in a hibel action. ${ }^{175}$

(1977). For instance, when an individual calls someone a "bastard" during an argument, then no defamation action will he, even though a factual assertion regarding parentage might be implied. But the Restatement adds that because written vulgarity requires reflection by the writer, these written vulgarities are intended to be taken seriously, and thus can be defamatory. In light of Milkovicl, this comment on written vulgaries is only valid where the vulgarity, in context, reasonably implies actual fact content. That the vulgarity is written is not sufficient, by itself, reasonably to imply actual fact content. Because the Spence court inakes no attempt to provide a factual analysis of the vulgar Hustler statements, it fails to meet the constitutional standard required under Milkovich.

174. See infra text accompanying notes 130-34.

175. See Philadelphia Newspapers, Inc. v. Hepps, 475 U.S. 767, 776 (1986). I leave unexamined, in this Note, the implications thay may stem from the "actual malice" burden imposed in cases involving public figures. 
If the reasonable reader could interpret a statement as conveying an exclusively non-libelous meaning, the plaintiff will be unable to prove by a preponderance of the evidence that the libelous reading is "inore" reasonable. Once the threshold of reasonableness is met by any exclusively non-libelous interpretation, the presence of a reasonable libelous interpretation does not negate the reasonableness of the non-libelous interpretation. The exclusively non-libelous reasonable interpretation, absent evidence of defamatory intent, will always carry at least equal weight with the libelous interpretation, inaking it impossible as a inatter of law for the libelous interpretation to be proven "more" reasonable. Nonetheless, allowing a jury to consider such a case invites a decision on the basis of which reasonable interpretation the jury prefers, and not whether the non-hibelous reading is reasonable and complete without a necessary alternative hibelous interpretation.

One inay also view this question from the perspective of tort law. Namely, is it reasonably foreseeable that a stateinent would be interpreted with a defamatory ineaning? The presence of a reasonable, exclusively non-hbelous interpretation shows that the defamatory ineaning is not reasonably foreseeable. Such a non-hibelous interpretation ineans that the writer could reasonably have made the assertion without conveying any other meaning to reasonable readers. The fact that an additional meaning inay have been conveyed does not inean that the language used made the additional ineaning foreseeable. Thus, the writer might reasonably make such an assertion without foreseeing any other interpretation.

Proof of the writer's intent to defaine would mean that the writer did foresee the hibelous interpretation, despite any reasonable, exclusively non-libelous interpretation. ${ }^{176}$ By this, I do not mean to suggest that proof of a writer's defamatory intent is always constitutionally necessary to prove that an opimion statement is capable of being interpreted with direct or implied factual content. No such proof of intent would be needed to show that a writer foresaw a defamatory ineaning where an exclusively non-libelous interpretation of a statement is not reasonable.

176. It might be argued that a writer's intent should be irrelevant to this discussion, and that the sole focus should be the reasonableness (or foreseeability, in tort analysis) of an interpretation as gauged by the reasonable reader. Because the reader is unaware of any intent on the writer's part not conveyed by the expression itself, the writer's non-expressed intent does not influence the reader's interpretation and does not add (or detract) from any potential defamatory meaning. However, in those instances where it can be demonstrated that a writer was aware of a defamatory interpretation, despite the presence of an alternative, exclusively non-defainatory reasonable interpretation, then the writer can argue less persuasively that her statement was reasonably non-defamatory. Perhaps this is just another way of stating that proof of intent to defame is evidence that a nondefamatory interpretation is not the exclusive interpretation. 
For example, suppose the basis of a libel action is the false written statement "Jack didn't sleep with his wife last might, he slept with Marie," where the statement is made im the context of a discussion of extramarital affairs, but no imtent of the writer can be shown. The statement can plainly be interpreted im at least two ways, one of which is non-defamatory: Jack sleeping (and only sleeping) with Marie. Nevertheless, the non-defamatory interpretation is not exclusive-it is unreasonable, in this context, to make the assertion that "sleep with" need not mean "to conduct an extramarital affair with." Thus, the non-libelous interpretation should not save this writer from a bibel action (assuming all other constitutional requirements, such as falsity, are also met).

Consider the following model. ${ }^{177}$ Suppose $\mathrm{X}$ is a road builder. $\mathrm{X}$ builds road A. Some time later paths $B$ and $\mathbf{C}$ are beat off of road A. At the time $\mathrm{X}$ built $\mathrm{A}$, she knew it adjomed a popular baseball stadium and it was foreseeable that passersby would try to beat a path (path B) to the stadium despite X's failure to do so. But X did not know, and could not reasonably have been expected to know, that some years later a popular movie theater would also be built in the vicimity of road A, leading passersby to beat path $\mathbf{C}$ off of $\mathbf{A}$.

If three pedestrians have three separate accidents on A, B and C, and they each sue $X$ for neghigence, what outcome should result? Certainly $\mathrm{X}$ can be held liable for the negligent construction of $\mathrm{A}$. And given the foreseeability of the creation of path $B$, it would also probably be reasonable to hold $\mathrm{X}$ hable for injury resulting from negligence associated with path $B$ (e.g., not posting a suitable warning sign, or building a fence). But $X$ should not be held responsible for an accident on path $C$, because such an accident was not reasonably foreseeable to $X$.

I mean to equate road A with a speaker's intended linguistic mean$\mathrm{mg}$, path B with a (libelous or non-libelous) reasonable interpretation of $A$, and path $C$ with an unintended, but reasonable, libelous interpretation of $A$. Although $C$ is as real as $A$ and $B, X$ should not be leeld accountable for this unforseen (to her) interpretation. The central analogy is this: To those who beat path $C$, a novel interpretation, off of road $A$, the new path is a reasonable outcome from road A. Yet road A's builder need not liave foreseen path $\mathrm{C}$ at all and should not be held accountable for an "accident" occurring due to path C.

177. The model is inspired by WITTGENSTEIN, supra note $1, \S 85$ ("A rule stands there like a sign-post-Does the sign post leave no doubt open about the way I have to go? Does it shew which direction I am to take when $I$ have passed it; whether along the road or the footpath or crosscountry?'). 
The word "exclusive" is critical to this entire argument. If the reasonable reader must see a defamatory as well as a non-defamatory interpretation, then the statement is not susceptible to an exclusive nondefamatory interpretation and should still be subject to libel suit. This is the case im Diadiun's column. Although at certain points in the column it is not clear if the "lie" being referred to is the alleged change im testimony or Milkovich's description of the fight, given Diadiun's explicit mention of both accusations, both interpretations of the term "he" are reasonably foreseeable. Only one of the two interpretations is potentially defamatory as an implied factual statement. But because the non-defamatory interpretation is not exclusive, Diadiun is still reasonably subject to a bibel suit, assuming the imphed facts are shown to be false and defamatory.

Suppose the column made no mention of the alleged change in testimony or to the due process nature of the Court of Common Pleas hearmg, but a court nonetheless interpreted the "lie" as referring to altered testimony. Because the court hearing was, in fact, solely concerned with due process, and the fight need not even have been discussed, sucli an interpretation might be reasonable to someone who independently of the article was familiar with the court hearing and nature of legal methods. ${ }^{178}$ But if a reasonable reader looking at the article by itself could interpret the alleged "he" as only referring to the fight, then this reasonable and exclusively non-defamatory (because it is a "pure" opmion) statement, should be exempt from a bibel action, notwithstanding the alternative understanding reached by the other reader.

\section{CONCLUSION}

In his dissent to Ollman v. Evans, ${ }^{179}$ then-Judge Scalia stated that "it is a normal human reaction, after pamstakingly examining and rejecting thirty mvalid and almost absurd contentions, to reject the thirtyfirst contention as well, and make a clean swecp of the matter."180 Nonetheless, Scalia made the point that a single defamatory statement should not escape hability just because it is buried among dozens of non-defamatory statements. ${ }^{181}$ But Scalia warned plaintiffs that wasting a court's

178. See Milkovich, 110 S. Ct. at 2714 (Brennan, J., dissenting) ("[T]o anyone who knows what 'due process' means, it does not follow that the court must have believed some he about what happened at the wrestling meet, because what happened at the meet would not have been germane to the questions at issue.").

179. 750 F.2d 970 (D.C. Cir. 1984), cert denied, 471 U.S. 1127 (1985).

180. Id. at 1036 (Scalia, J., dissenting).

181. See id. at 1035. 
time with a long hist of obviously non-defamatory statements risks having the one actually defamatory passage lost in the fray. ${ }^{182}$

With Milkovich, the problem that Scalia identified in Ollman has come full circle. Just because one potentially defamatory imphed fact is found among a litany of protected opimions does not mean that all of the opinions in the challenged statement are potentially defamatory.

Read properly, Milkovich represents an affirmation of the constitutional protection for statements of opinion. Given the interminghing of fact and opinion in nearly any controversial stateinent, however, the task is not easy for a trial court faced with a defamation action based on an expression containing facts-soine iniphedly stated, some directly stated-and opinions. But it is the constitutional responsibility of the trial court not to allow "pure" expressions of opinion to become the subject of the trial. The limitation of evidence and arguments to the factual or implied factual assertions contained in a stateinent is essential to keep a jury (or judge) from being teinpted to condemn a speaker for her point of view, and not for a defamatory falsehood. 